\title{
On appraising alternative power plant investment proposals Part 2: application
}

\author{
J E A Roy-Aikins ${ }^{1 *}$ and D Bohn ${ }^{2}$ \\ ${ }^{1}$ Department of Mechanical Engineering, University of Durban-Westville, Durban, South Africa \\ ${ }^{2}$ Institute of Steam and Gas Turbines, Aachen University of Technology, Aachen, Germany
}

\begin{abstract}
This paper is an application of the economic model developed in Part 1 and programmed in the computer code PEACES (program for the economic analysis of combined energy systems). A case study is presented in which hypothetical energy requirements at an industrial site are considered and an exercise is conducted wherein cogeneration is considered as a means of improving the energy situation at the site. Appropriate technologies that can satisfy the cogeneration requirements are investigated and technical and economic evaluations are carried out for a feasibility assessment. Of the three proposals considered, the gas turbine with heat recovery steam generator and the gas/steam turbine combined cycle cogeneration plant were found to be economically viable, while the steam turbine was not. It was recommended that the gas/steam turbine combined cycle cogeneration proposal be adopted, as it was the most economical.
\end{abstract}

Keywords: cogeneration, combined cycles, combined heat and power, energy systems analysis, power plant economics

\section{INTRODUCTION}

The energy curves for a particular industrial site are available. These were used to create a hypothetical problem where management were contemplating adopting measures that could reduce the annual energy bill for the site. An engineering consulting firm was approached to study the situation and to make recommendations, if necessary, on how best an improvement in the energy situation at the site could be implemented. The only constraint was that an interruption in energy supply must not occur, as this would adversely affect production schedules, in addition to being costly.

Preliminary investigations showed that cogeneration of heat and power was the best means of achieving an increase in energy efficiency at the site, and that it could, in principle, be implemented successfully. The problem is considered in this paper and the procedures applied in finding a solution are presented. A detailed technical analysis of the alternatives is carried out and the computer code PEACES (program for the economic analysis

The MS was received on 25 February 1999 and was accepted after revision for publication on 11 January 2000.

*Corresponding author: Department of Mechanical Engineering, University of Durban-Westville, Private Bag X54001, Durban, South Africa.

A02399 (C) IMechE 2000 of combined energy systems) is used to determine the most economically viable option.

\section{THE DESIGN PROBLEM}

\subsection{The existing system}

A schematic of the existing energy system is shown in Fig. 1. Steam is generated in two heat-only boilers at saturation conditions at 10.1 bar. Boiler I is rated at 18 ton $/ \mathrm{h}$ and boiler II at $38 \mathrm{ton} / \mathrm{h}$. Both are fired on distillate oil. Depending on the season, the steam from the header is fed into two lines, one of which goes to calorifiers where heat for space heating is produced, and the other to the process. A small amount of steam is bled off from the process line to feed the deaerator, in addition to flash steam obtained from steam drum blow-down. The condensate from the process and calorifiers are mixed with make-up water before entering the deaerator. Some amount of hot water for use at the site is taken from the deaerator storage tank. All the electrical energy required at the site is bought from the grid.

The energy curves available are shown in Figs 2 and 3. The average monthly consumption of steam and (electrical) power are shown in Fig. 2, while the hourly site 


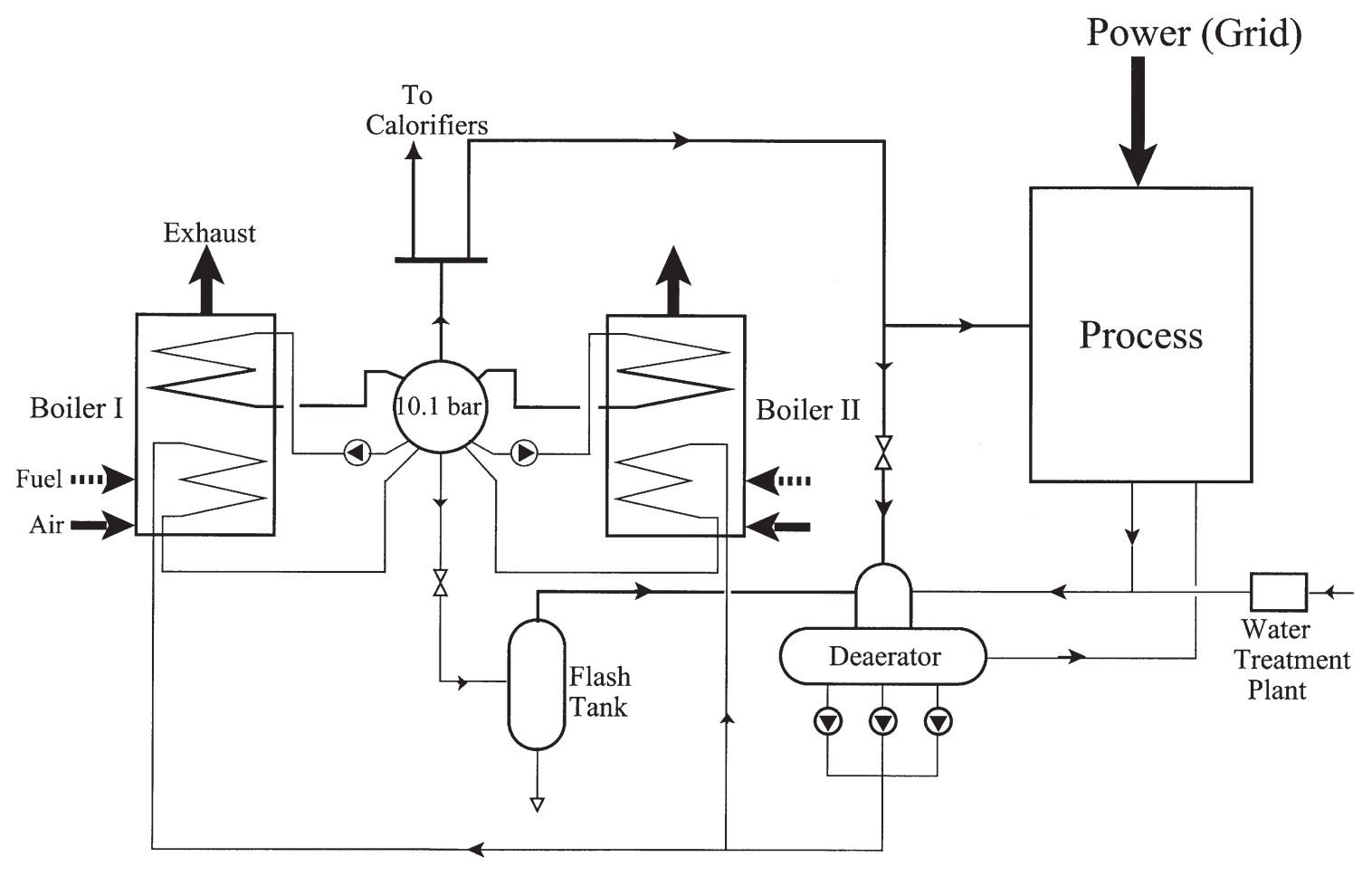

Fig. 1 The existing system

requirements for days typical of each season are shown in Fig. 3. The curves in Fig. 3 are assumed to represent the energy requirements at the site. The number of days in the year, $n$, for which each curve is applicable is shown in the figure. It is seen that the power required at the site is just about constant throughout the day during each season and that there is a slight variation in power over the year (clearly seen in Fig. 2). During each season, the amount of steam generated varies during the day (Fig. 3), although not appreciably. There is, however, an appreci- able variation in the amount of steam required over the seasons (Figs 2 and 3). This represents a mismatch of loads, which must be taken into consideration when the type of power plant and the control strategy are being decided on for cogeneration application.

\subsection{General considerations}

A three-shift system operates at the site to cater for a

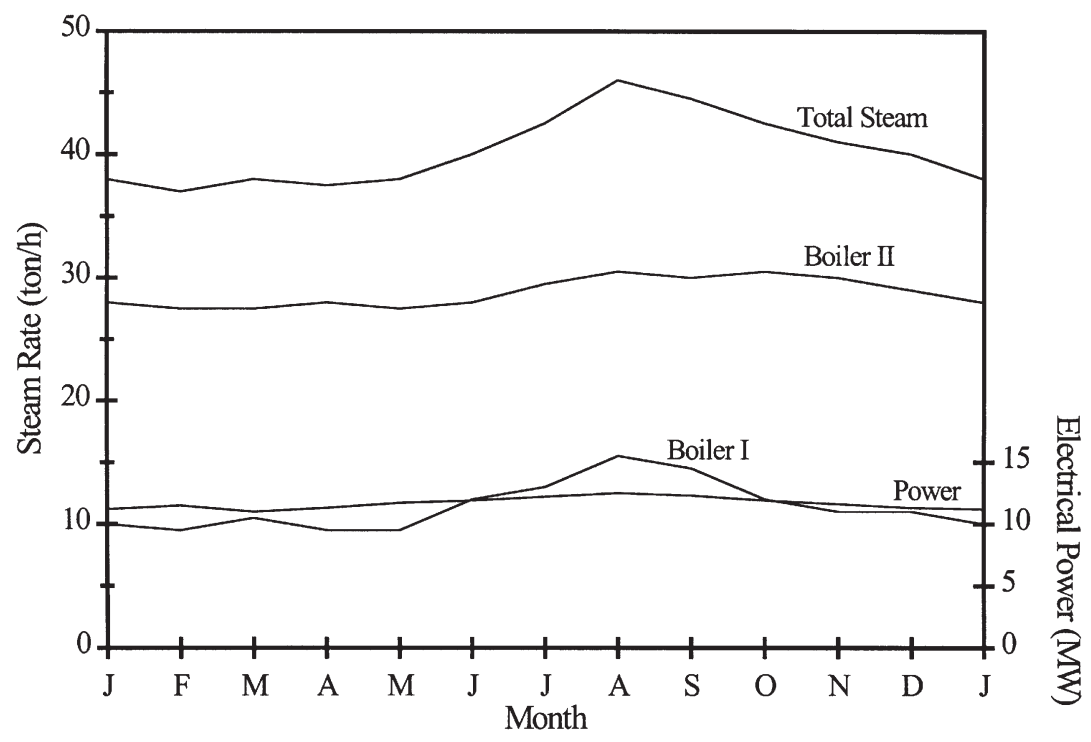

Fig. 2 Annual site demands 


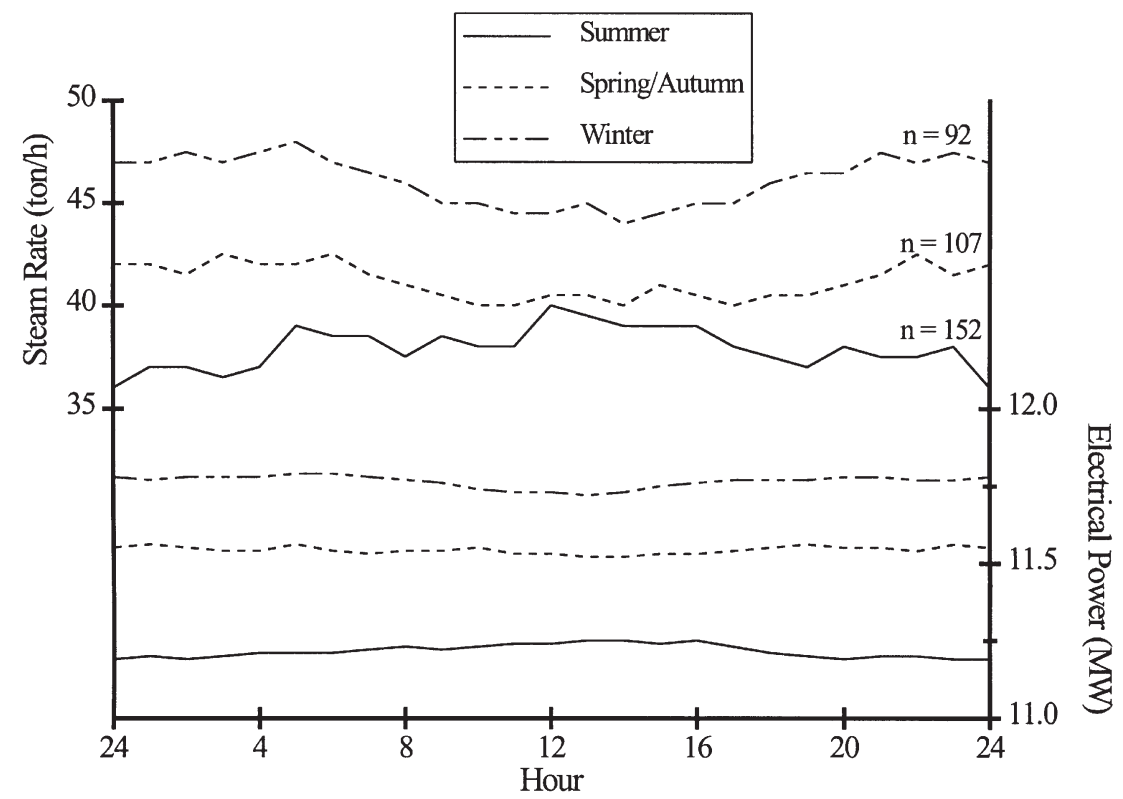

Fig. 3 Typical seasonal site requirements

daily $24 \mathrm{~h}$ production schedule. The plant is in operation throughout the year except at the end of the year when it is shut down for 14 days, during which maintenance is carried out. A change in boiler fuel only was not considered as a candidate for improving the energy situation at the site as the current fuel used is clean enough and a cheaper alternative of acceptable performance is not available. Thus, an improvement in the energy situation at the site could be achieved only by incorporating on-site generation of power, which would require the installation of a new power plant. The requirement that an interruption of energy supply must not occur dictates that the site electrical power system be connected to the grid so that power can be bought in whenever the power plant is unavailable. This is more economical than providing back-up power. The assumption is that the local power authority is able to provide the site with power whenever it is needed and that the opportunity exists for excess power to be sold to the grid.

Separate generation of power and heat is generally not the most economical way of producing heat and power for a site and so the addition of a power-only plant to the existing energy system was not considered. Consequently, a combined heat and power plant was chosen for the duty. The present boilers are retained so that full steam is available in the event of the power plant being unavailable. This allows for the use of one or both boilers to be factored into the sizing of the power plant in case the steam produced by the power plant needs to be augmented.

The power plant can be operated in one of three possible load modes, i.e. the heat-following, powerfollowing and maximum power modes. In the heatfollowing mode, the power output of the plant may be less or greater than the electrical load, and as such power must be imported into or exported from the site. In the case where power is exported, the power produced may be less than the maximum that can be produced. Maximum use is then not being made of cogeneration, and as such the plant is not being operated in the most economical way. In the power-following mode, the heat produced may not be sufficient and must be augmented. If the heat is too much, some of the gases should be diverted away from the heat recovery boiler through a second stack (and as such wasted), or the extra steam generated can be injected into the power plant, if possible. This is also the case when the plant is operated in the maximum power mode, which allows for the export of the maximum power possible and results in a more economical way of operating the plant. In the light of these considerations, gas and steam turbine systems were examined and compared to determine the most economical option. Diesel plants were excluded as they were thought to have low heat-power ratios for this duty.

\section{PLANT DESCRIPTIONS}

Three different cogeneration technologies operating on the Brayton and/or Rankine cycle were considered for meeting the energy needs at the site. These are a steam turbine, a gas turbine with a heat recovery steam generator (HRSG) and a gas/steam turbine combined cycle cogeneration plant. The basis of the comparison is that all the plants are sized to produce 34.7 MW (45 ton $/ \mathrm{h}$ ) of saturated steam at $10.1 \mathrm{bar}$, which is sufficient to cover the 'non-winter' heat loads. The heat produced will 
be supplemented during the winter months with heat from boiler I. Usually, suitable machinery and components are chosen from what is available in the market to constitute the power plant. Part-load performance characteristics are required to carry out a detailed analysis of the energy system. As no such performance curves were available, the computer program BRAKINE [1] was used to design all the power plants and to generate their offdesign performance characteristics. The operational strategy adopted usually for cogeneration plants is such that maximum economic benefits are derived from the operation of the plant. In this study, this was achieved by operating the plant at the allowable maximum power for base load operation. This ranged from 89 to 94 per cent power for the three plant types investigated.

In all the alternatives, the return from the process is mixed with make-up water and fed to the deaerator. The steam for the deaerator is bled from that generated for the process, with a small fraction coming from blow-down flash. Some amount of hot water is taken from the deaerator to provide services at the site.

\subsection{Steam turbine}

An extraction condensing steam turbine optimized for throttle conditions 63 bar and $420^{\circ} \mathrm{C}$ and a condenser pressure of 0.5 bar was designed. This type of turbine is not the simplest, and hence cheapest, for this application. A back pressure turbine exhausting to process pressure would generate power short of the site's needs, which would require the purchase of power from the grid. This was to be avoided. A desuperheater is required to desuperheat the steam to saturation conditions. To produce $34.7 \mathrm{MW}$ of process heat, $107 \mathrm{ton} / \mathrm{h}$ of steam
Table 1 Design point plant performance

\begin{tabular}{llll}
\hline & & & $\begin{array}{l}\text { Gas-steam } \\
\text { turbine } \\
\text { combined } \\
\text { cycle }\end{array}$ \\
& $\begin{array}{l}\text { Steam } \\
\text { turbine }\end{array}$ & $\begin{array}{l}\text { Gas turbine } \\
\text { with HRSG } \\
\text { cogeneration }\end{array}$ \\
\hline Gas circuit & & & \\
Compressor airflow $(\mathrm{kg} / \mathrm{s})$ & & 70.9 & 84.5 \\
Compressor pressure ratio & & 9.5 & 9.5 \\
Turbine inlet temperature $\left({ }^{\circ} \mathrm{C}\right)$ & & 980 & 980 \\
Exhaust gas mass flow $(\mathrm{kg} / \mathrm{s})$ & & 72.2 & 86.1 \\
Exhaust gas temperature $\left({ }^{\circ} \mathrm{C}\right)$ & & 506.5 & 506.5 \\
Stack temperature $\left({ }^{\circ} \mathrm{C}\right)$ & & 108.6 & 108.6 \\
Electrical output $(\mathrm{MW})$ & & 18.0 & 21.5 \\
Steam circuit & & & \\
Throttle pressure $(\mathrm{bar})$ & 63 & & 63 \\
Throttle temperature $\left({ }^{\circ} \mathrm{C}\right)$ & 420 & & 520 \\
Steam rate $(\mathrm{kg} / \mathrm{s})$ & 29.6 & 13.1 & 15.0 \\
Turbine exhaust pressure & 0.5 & & 10.3 \\
Deaerator pressure & 10 & 10 & 10 \\
Electrical output $(\mathrm{MW})$ & 15.7 & & 5.5 \\
Total electrical output $(\mathrm{MW})$ & 15.7 & 18.0 & 27.0 \\
Thermal output $(\mathrm{MW})$ & 34.7 & 34.7 & 34.7 \\
Heat rate $(\mathrm{Btu} / \mathrm{kW}$ h) & 18544 & 10884 & 8665 \\
\hline
\end{tabular}

is generated. The power output is $15.7 \mathrm{MW}$, which is greater than the site's needs. The plant is shown schematically in Fig. 4 and the design point performance is given in Table 1. The part-load performance is shown in Fig. 5.

\subsection{Gas turbine application}

A free-turbine gas turbine of pressure ratio 9.5 and of turbine inlet temperature $980^{\circ} \mathrm{C}$ was designed as the base gas turbine unit. The back pressure will be modified to

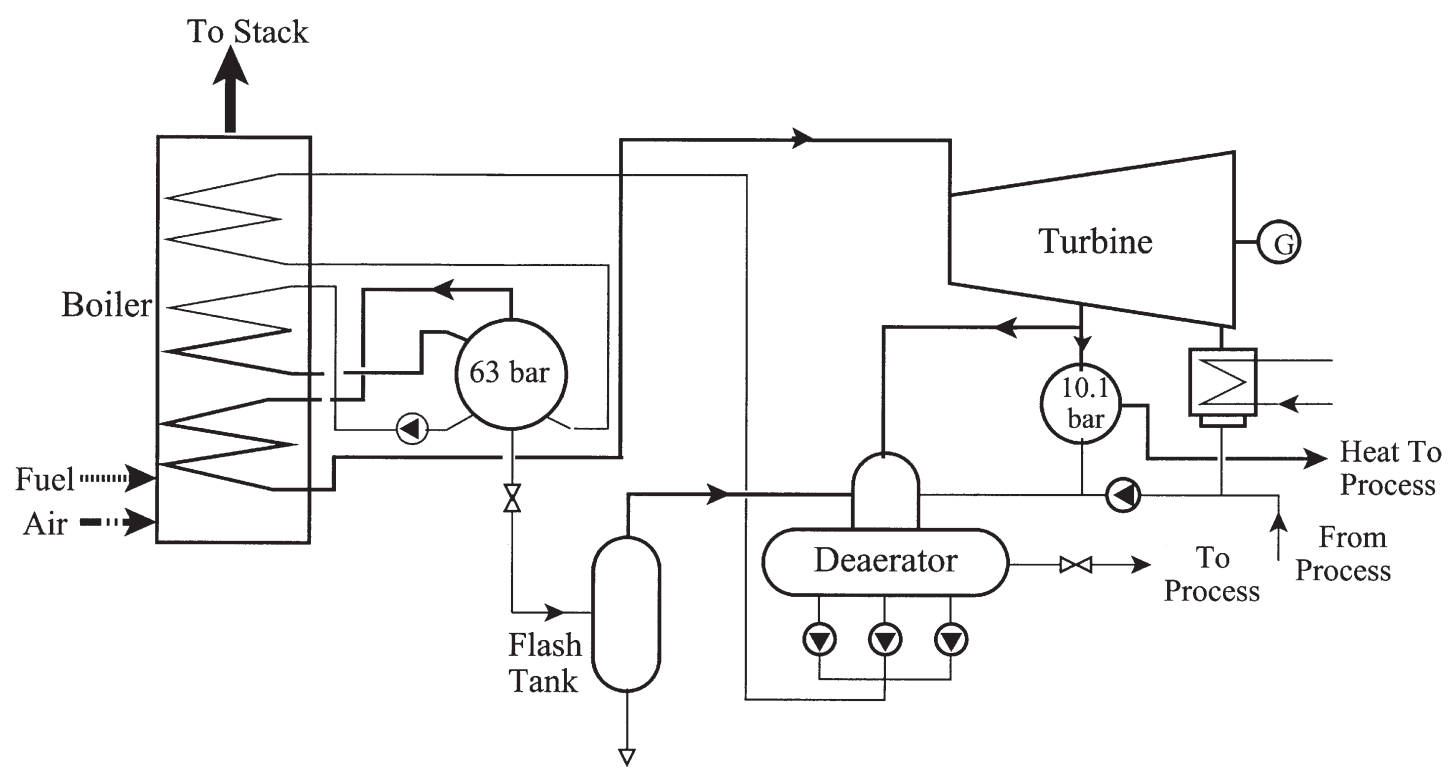

Fig. 4 The steam turbine plant 


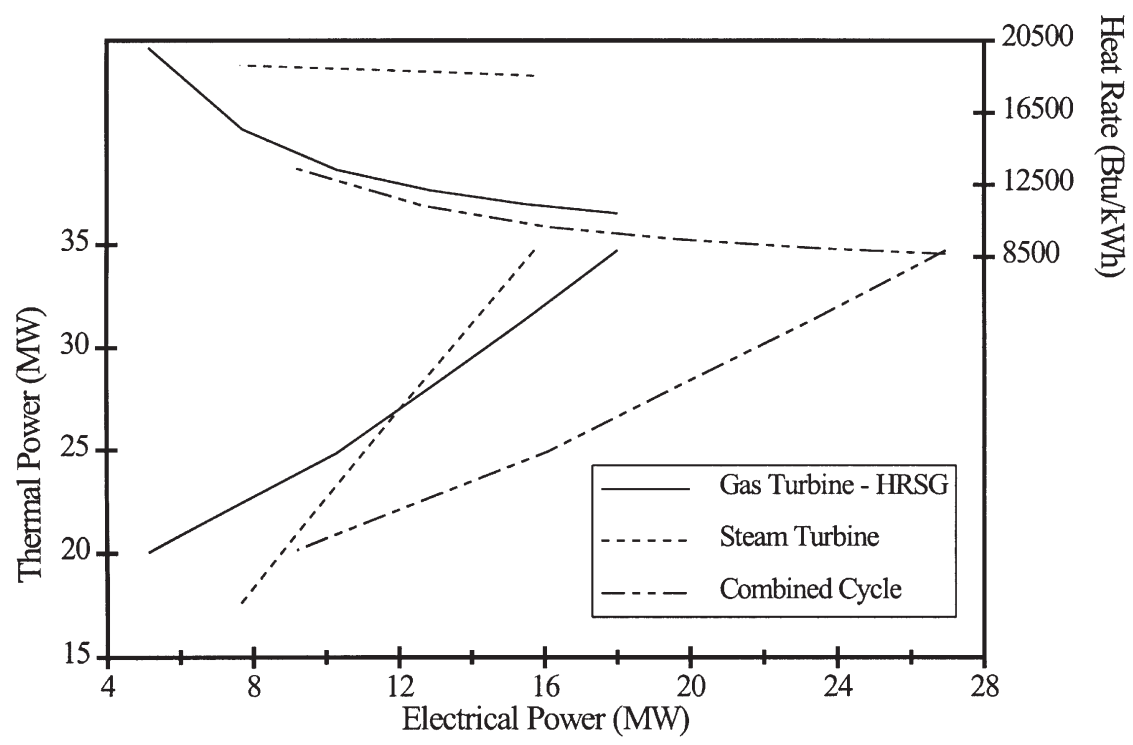

Fig. 5 Plant performance characteristics

account for pressure losses in the exhaust system, and the gas path will be scaled to produce a plant of any desired output.

\subsubsection{Gas turbine with an HRSG}

A gas turbine with an HRSG was thought to be the simplest arrangement for producing saturated steam. Supplementary firing was not considered as additional heat can be produced in the existing boilers, if necessary, and steam injection was ruled out because of complexity.
A compressor airflow of $70.9 \mathrm{~kg} / \mathrm{s}$ was required to give the design heat output of $34.7 \mathrm{MW}$, and the resulting power output was 18.0 MW. A schematic of the plant is shown in Fig. 6 and its performance at the design point is given in Table 1. The part-load performance characteristics are shown in Fig. 5.

\subsubsection{Combined cycle plant}

The combined cycle plant designed required a bigger gas turbine than that used with the HRSG arrangement, to

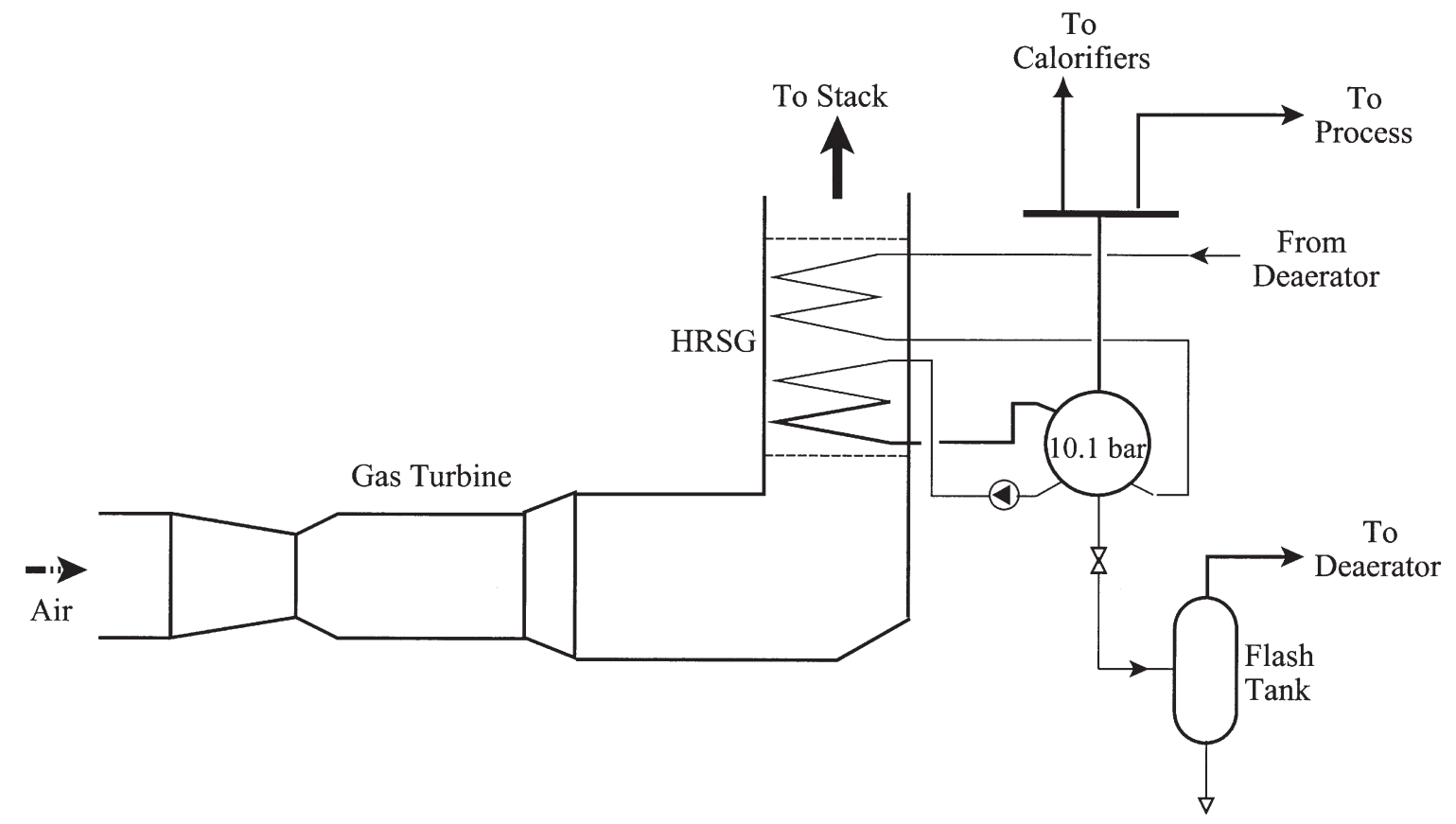

Fig. 6 The gas turbine with heat recovery steam generator 


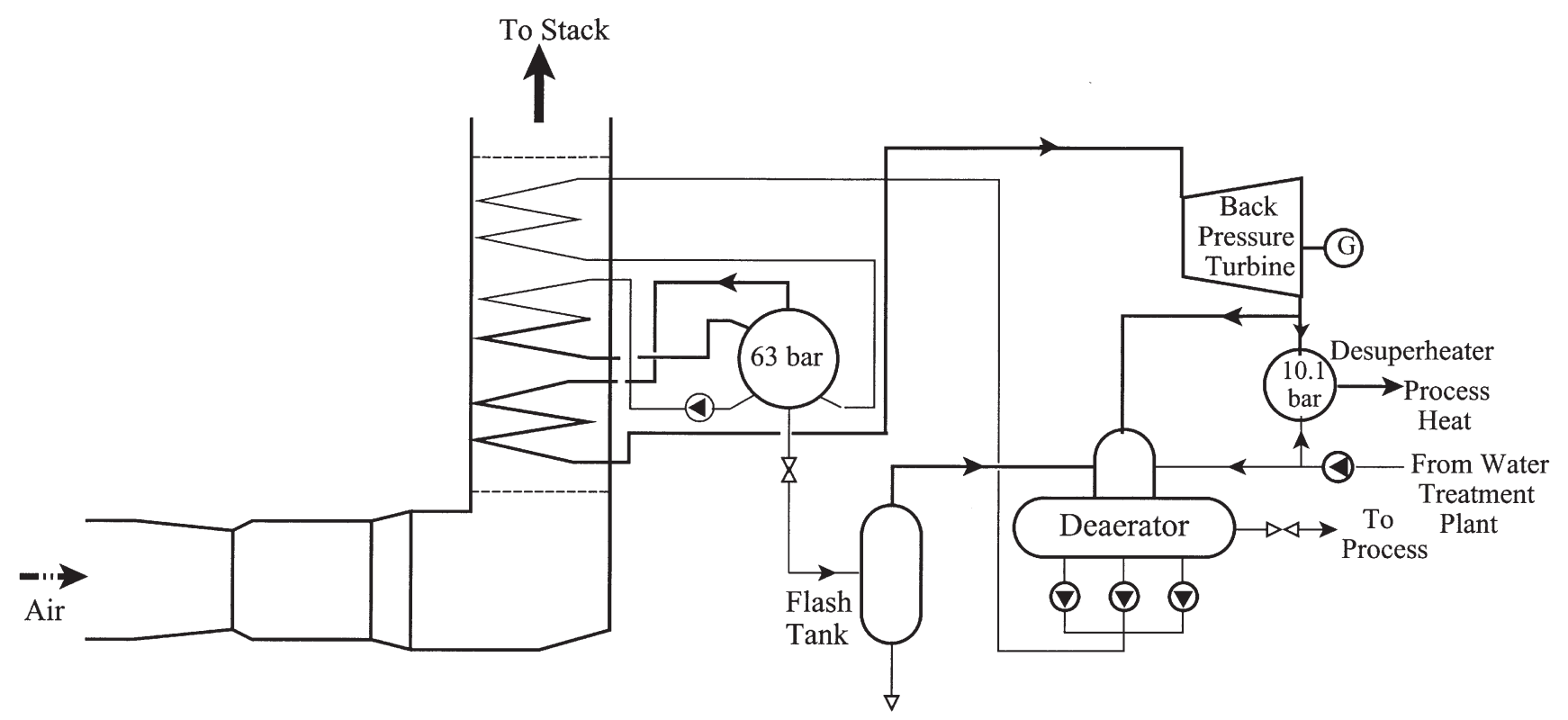

Fig. 7 The combined cycle cogeneration plant

provide additional energy to superheat the steam generated. A simple back pressure turbine with the same throttle conditions as the steam turbine plant exhausts to a pressure slightly above process pressure. A desuperheater is required here also. The gas turbine generates $21.5 \mathrm{MW}$ of power while the steam turbine generates 5.5 MW. The same amount of heat as produced in the other plants is generated and the heat rate is the most excellent. A schematic of the plant is shown in Fig. 7 and its performance data at the design point are given in Table 1 . The off-design characteristics are shown in Fig. 5.

\section{ECONOMIC ANALYSIS}

Various life cycle costs and financial data are required in addition to the load curves to carry out an economic analysis of the alternatives. These were introduced in Part 1 of the paper. The financial data are common to all alternatives, while the life cycle costs data, from which the yearly cash flows are obtained, as depicted in Fig. 1 of Part 1, may be alternative specific. The financial data used in the analysis are given in Table 2, while the life

Table 2 Financial data

\begin{tabular}{ll}
\hline Nominal equity interest rate $i_{\mathrm{e}}(\%)$ & 27.5 \\
Nominal debt interest rate $i_{\mathrm{d}}(\%)$ & 20.5 \\
Income tax rate $\tau(\%)$ & 40 \\
Inflation rate $e_{\mathrm{i}}(\%)$ & 7.5 \\
Equity fraction of capital $\alpha_{\mathrm{e}}$ & 0.44 \\
Equipment life (years) & 25 \\
Tax life (years) & 10 \\
Salvage value $(\$)$ & 0 \\
\hline
\end{tabular}

cycle costs data are given in Table 3 , for both construction and operation phases. The economic performance parameter used here for comparison is the net present value. The cost of electricity will also be evaluated for comparison. The procedures for evaluating the elements in the economic model given in Fig. 2 of Part 1 now follow. The analyses presented are for the cogeneration plants. Similar analyses are carried out for the boiler, where applicable, to determine the costs associated with

Table 3 Life cycle costs data

\begin{tabular}{|c|c|c|c|}
\hline & $\begin{array}{l}\text { Steam } \\
\text { turbine }\end{array}$ & $\begin{array}{l}\text { Gas turbine } \\
\text { with } \\
\text { HRSG }\end{array}$ & $\begin{array}{l}\text { Gas-steam } \\
\text { turbine } \\
\text { combined } \\
\text { cycle } \\
\text { cogeneration }\end{array}$ \\
\hline \multicolumn{4}{|l|}{ Capital costs } \\
\hline Bare equipment cost $(\$ / \mathrm{kW})$ & 1017 & 697 & 815 \\
\hline Shipping cost $(\%)$ & 4.9 & 5.4 & 4.4 \\
\hline Construction cost $(\%)$ & 8.1 & 8.8 & 6.8 \\
\hline Start-up capital $(\%)$ & $6: 3$ & 8.0 & 4.5 \\
\hline Construction time (years) & \multicolumn{3}{|c|}{2} \\
\hline Payment schedule (\%) & \multirow{2}{*}{\multicolumn{3}{|c|}{$\begin{array}{l}40,60 \\
\text { Inflation rate }\end{array}$}} \\
\hline Escalation rate $(\%)$ & & & \\
\hline Fixed yearly disbursements (\%) & 2 & 2 & 2 \\
\hline \multicolumn{4}{|l|}{ Operation and maintenance } \\
\hline Fixed $(\$ / \mathrm{kW})$ & 9.79 & 1.0 & 13.19 \\
\hline Incremental $(ф / \mathrm{kW} \mathrm{h})$ & 0.959 & 1.000 & 0.340 \\
\hline \multicolumn{4}{|l|}{ Fuel cost (\$/GJ) } \\
\hline Kerosene & & 4.90 & \\
\hline Residual fuel oil & & 4.02 & \\
\hline \multicolumn{4}{|l|}{ Average electricity cost ( $\varnothing / \mathrm{kW} \mathrm{h})$} \\
\hline Bought in & & 5.39 & \\
\hline Bought back & & 3.47 & \\
\hline
\end{tabular}


the extra heat generated in the boilers. The reference year is January 1998 and the analysis is carried out for the South African economy.

The equation numbers cited are those in Part 1 of the paper.

\subsection{Capital costs}

The capital cost of the project is required, as this constitutes the starting point of the calculations. As given in Table 3, the total capital invested in the project is expressed as a factor of the bare equipment cost. This is required to obtain the capitalized investment, equation (10) of Part 1, which is what appears in the books of the firm as the value of the plant, and which must be recovered.

The capital recovery charge is usually the second or third largest cost item in the revenue requirement for power plant investment projects. It is important, therefore, that equipment cost be estimated very accurately to minimize errors in calculating the capital recovery charge. The estimates of equipment cost were obtained with the aid of published data $[2,3]$. The book value of the boilers is a sunk cost and therefore does not appear in the economic analysis. However, the $\$ 0.9$ million that was estimated as the cost of refurbishing the boilers is taken into account when evaluating the capital charge for the boilers.

The construction payment schedule shown in Table 3 is used to capitalize the investment. It is expected that the erection of the new facility will be completed within 15 18 months. For accounting purposes, the construction time is taken as 2 years. The capitalized investments for the three alternatives are shown in Table 4.

\subsection{Revenue}

In the separate generation of heat and power, the electrical energy used at the site is bought from the grid at the unit buy-in rate, while the heat required is produced

Table 4 Plant economic performance

\begin{tabular}{|c|c|c|c|}
\hline & $\begin{array}{l}\text { Steam } \\
\text { turbine }\end{array}$ & $\begin{array}{l}\text { Gas turbine } \\
\text { with } \\
\text { HRSG }\end{array}$ & $\begin{array}{l}\text { Gas-steam } \\
\text { combined } \\
\text { cycle } \\
\text { cogeneration }\end{array}$ \\
\hline Capitalized investment $\left(10^{6} \$\right)$ & 20.4 & 16.4 & 27.0 \\
\hline Thermal output (GW h) & 267.1 & 267.1 & 267.1 \\
\hline $\begin{array}{l}\text { Generated electrical output } \\
(\mathrm{GW} \text { h) }\end{array}$ & 124.5 & 140.7 & 209.5 \\
\hline Excess electrical output (GW h) & 28.0 & 44.2 & 113.0 \\
\hline Net present value $\left(10^{6} \$\right)$ & -7.8 & 5.7 & 15.5 \\
\hline $\begin{array}{l}\text { Levellized net present value } \\
\qquad\left(10^{6} \$\right)\end{array}$ & -1.8 & 1.3 & 3.7 \\
\hline Cost of electricity $(\varnothing / \mathrm{kW} \mathrm{h})$ & 9.20 & 5.23 & 3.20 \\
\hline
\end{tabular}

A02399 (C) IMechE 2000 in boilers at the required generation cost. The cost of the energies used at the site is thus the sum of these two costs and is referred to as avoided cost. With cogeneration, the cost of producing heat and power in the cogeneration plant is referred to as production cost. When additional heat is produced in the heat-only boilers and/or electricity is bought in from the grid, the costs for these are added to the production cost to obtain the operating cost, which appears in the economic model. Therefore, with cogeneration, revenue, as it appears in the economic model, is equal to the avoided cost plus any proceeds from the sale of excess electricity to the grid. Excess electricity is sold at the buy-back price. The cost of heat and power from the cogeneration plant that is used at the site is the difference between the production cost and the proceeds from the sale of excess electricity to the grid. In addition to knowledge of the energy costs, the energy demand curves of Fig. 3 and supply curves of Fig. 8 are used to arrive at the value for revenue. The unit energy costs are given in Table 3. Provision is made for an increase or a decrease in plant output to cater for load growth and cutback associated with increased demand, with lower plant output in the early stages after commissioning and with ageing of the plant toward the end of project life. It is assumed that the plants are operated such that the electrical power delivered are at 95 per cent of their nominal desired base loads in the first year of operation, at 100 per cent over the next 22 years and at 90 per cent over the last 2 years.

\subsection{Production costs}

Production costs are made up of a few cost items, which include debt interest. Debt interest is tax deductible here. The analysis given below relates to the cogeneration plant. A similar analysis is carried out for the boilers, as necessary, to determine the production costs associated with generating extra heat in the boilers.

\subsubsection{Fuel cost}

A cogeneration plant should be utilized such that the owner realizes maximum economic benefit. In certain cases, this is dictated not by the demand load but by the manner in which the plant is operated. Maximum economic benefit is realized from cogeneration when the plant is operated such that maximum electricity is produced. Thus, the maximum excess electricity is sold to the grid (where applicable), i.e. when the plant is operated at the maximum base load power. Thus, fuel consumption could be in excess of what is required to produce the energies required at the site

Fuel cost is determined by equation (24) of Part 1, which requires the use of the supply load curves of the plant and plant performance characteristics, i.e. Figs 8 and 5. Two fuel oils are available for use at the site. These 


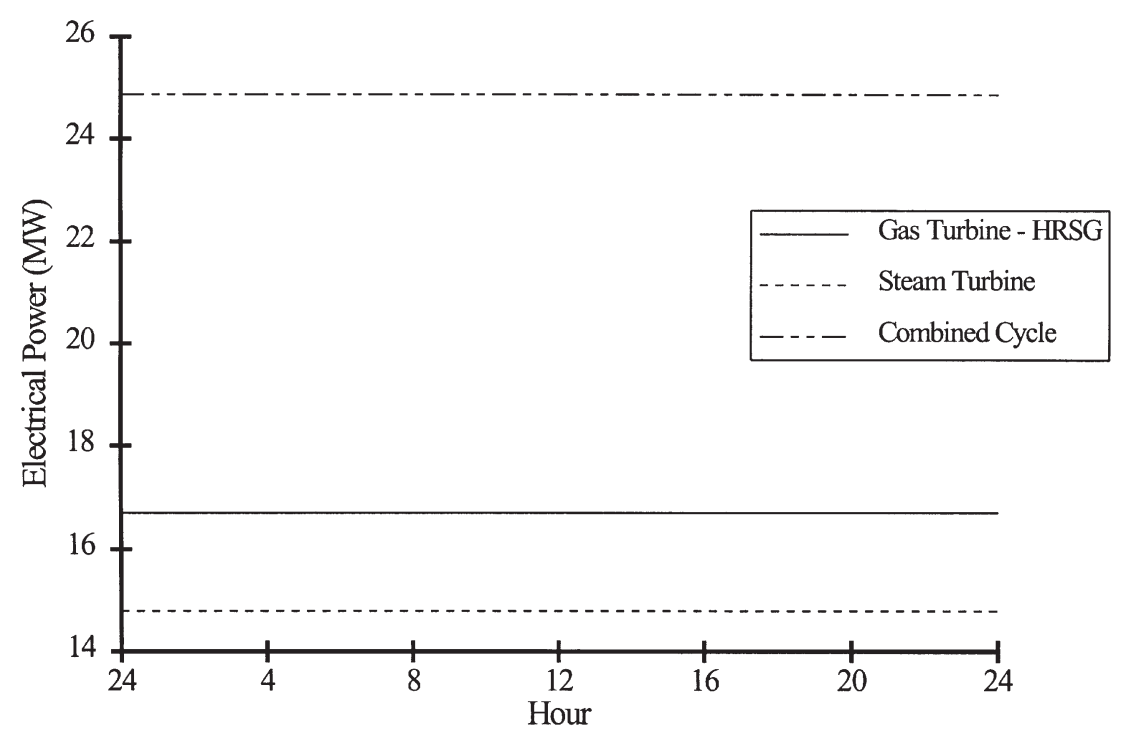

Fig. 8 Plant daily power output

are kerosene and residual fuel oil. The unit costs of these are given in Table 3 .

\subsubsection{Operation and maintenance}

Operation and maintenance cost comprises fixed and variable components. The product of plant capacity and the fixed operation and maintenance rate given in Table 3 gives the fixed operation and maintenance cost, while the product of the yearly energy output and the operation and maintenance incremental rate gives the variable operation and maintenance cost. These are applicable to the power plant and the boilers. Since miscellaneous costs comprise fixed and variable costs, these are lumped with the operation and maintenance cost through the fixed and incremental rates given in Table 3 . The energy outputs in year 1 are given in Table 4 .

\subsubsection{Depreciation}

A linear amortization of the investment is carried out over the life of the investment. The yearly plant depreciation is thus the quotient of the difference between the capitalized investment and plant salvage value and amortization life. The equipment and tax lives are given in Table 2.

\subsubsection{Debt interest}

Debt interest is the interest on debt owed at the beginning of a year. This is calculated from equation (15) of Part 1. Knowledge is required of the amount of debt retired during the previous year. This is the only variable in the expression. It is assumed that the principal debt is paid back in equal yearly amounts over the life of the equipment.

\subsection{Gross income}

The savings made from opting for cogeneration instead of the separate generation of heat and power is the difference between revenue and production costs and is referred to as gross income.

\subsection{Taxable income}

Taxable income is obtained by deducting tax depreciation and allowable deductions from the gross income. A straight-line depreciation is taken over the tax-depreciable life of the investment and the first $\$ 100000$ of gross income is exempted from tax. This figure is assumed to increase linearly to $\$ 150000$ in the last year of operation.

\subsection{Net income}

Applying the income tax rate of 40 per cent to the taxable income yields the income tax payable. Deducting income tax from and adding tax depreciation and allowable deductions to taxable income gives the net income, which can be separated into capital recovered and interest on equity. Debt interest was charged to production cost.

\subsection{The economic indicators}

\subsubsection{The net present value}

The yearly net incomes are present valued and the net present value is found, which is levellized. The most attractive investment proposal is that with the highest net present value or levellized net present value. 


\subsubsection{The cost of electricity}

The cogeneration plant produces both electricity and heat. Since the heat could have been produced in the boilers, the cost of the heat produced by the cogeneration plant is the incremental cost of producing the heat in the boilers and not the cost of producing the heat in an imaginary boiler, as is usually assumed. The difference between the production cost and the incremental cost is the cost of the electricity produced by the plant. This will be higher than what is found usually, but this procedure implicitly accounts for the unavailability of the cogeneration plant, whereas the usual procedure does not.

\section{RESULTS}

The results obtained for each technology type are compared in Table 4. The entire system, which includes the boilers, is reported. It is seen clearly that the gas/ steam turbine combined cycle cogeneration plant is the most economically viable option, having the highest net present value and the lowest production cost of electricity. These are $\$ 15.5$ million and $3.20 \notin / \mathrm{kW} \mathrm{h}$ respectively. The second most attractive option is the gas turbine with HRSG.

\section{DISCUSSION}

Simply, the net present value is the profit or loss to be made over the life of the project, quoted in 1998 dollars. Positive net present values for the two gas turbine based technologies indicate that these two investment proposals are economically viable, whereas a negative value for the proposal utilizing the steam turbine indicates that the investment is uneconomical. Therefore, the steam turbine system is not a contender to replace the existing energy system.

The reasons for the differences in economic performance of the three types of energy system are seen clearly in Fig. 9. The economic performance figures for the boilers are excluded from the figure, as the amount of

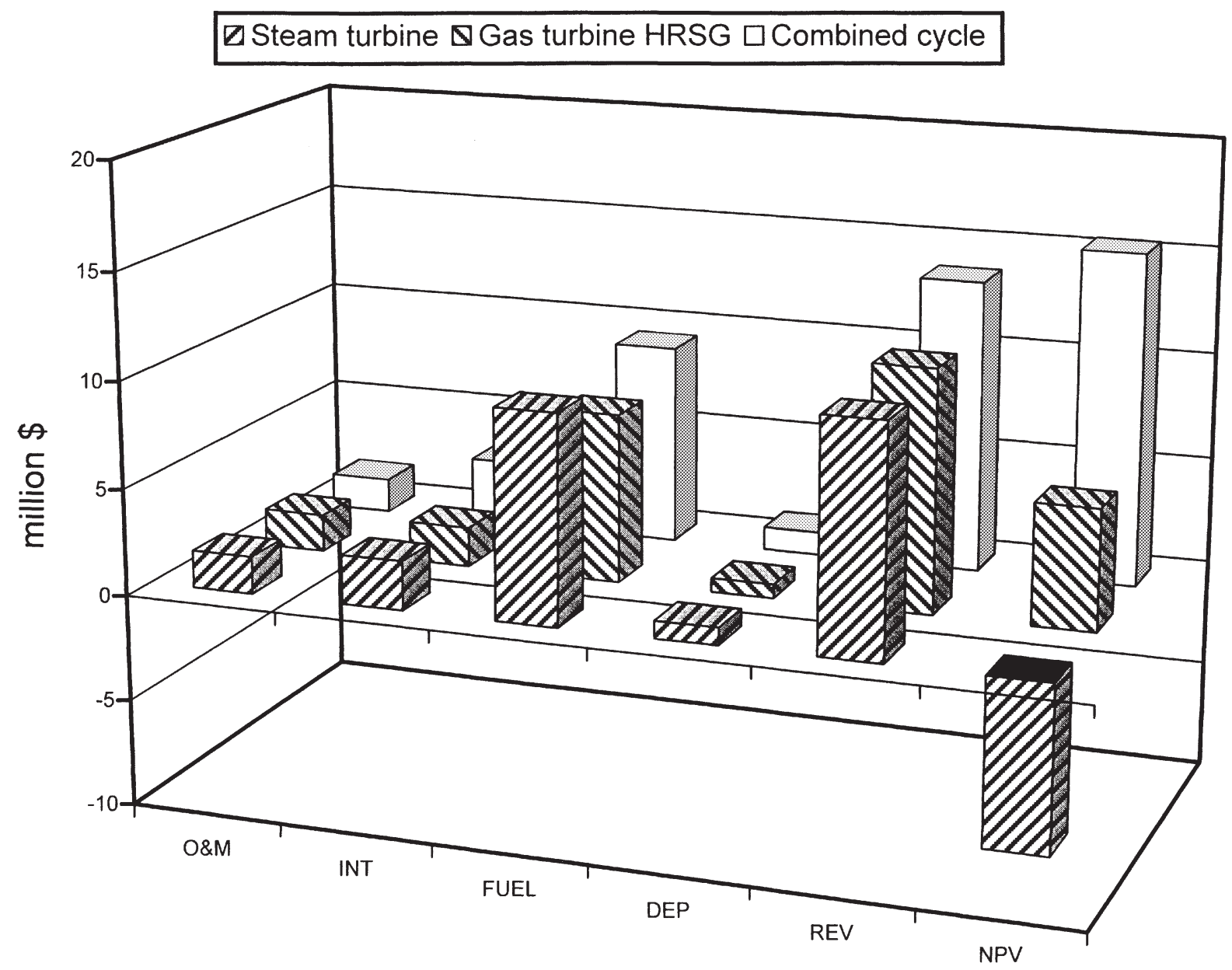

Fig. 9 Distribution of costs data 
heat produced by the boilers is the same regardless of the type of power plant. The cost of producing the power and heat generated in the power plant is the sum of the operation and maintenance, debt interest, fuel and depreciation costs. These quantities are shown in Fig. 9 for the first year of operation, and they vary with the size of the investment or the size of the plant or the scale of the thermodynamic performance of the plant. The production costs for the first year of operation are \$14.67, \$12.19 and \$15.14 million for the steam turbine, gas turbine with HRSG and the combined cycle cogeneration plants respectively. These are in the order of plant capitalized investment, and the trend is the same in every year of operation.

Revenue charged against operating cost comes from revenue earned from the sale of excess electricity and the savings made by displacing purchased electricity and boiler heat with electric and thermal energies produced by the power plant. The credit for electricity is the same for each system, $\$ 5.1$ million, while that for heat varies insignificantly from $\$ 4.738$ to $\$ 4.746$ million. For all practical purposes, it can be assumed that the savings made by generating electrical and thermal energies in the plants are the same in all cases. Hence, differences in revenue stem from differences in revenue earned from the sale of excess electricity. These are $\$ 0.95, \$ 1.50$ and $\$ 3.84$ million for the steam turbine, gas turbine with HRSG and combined cycle cogeneration systems respectively for excess electrical energies of 28.0, 44.2 and $113.0 \mathrm{GW}$ h respectively. Hence, the key to the economic attractiveness of each proposal lies in the electrical capacity of the plant, as all alternatives were sized for the same thermal output.

The levellized costs of electricity are 9.20, 5.23 and $3.20 \mathrm{~kW} \mathrm{~h}$ for the steam turbine, gas turbine with HRSG and combined cycle cogeneration plants respectively. These figures were arrived at as explained in Section 4.7 .2 , i.e. by assuming that the cost of producing power and heat in the power plant was the production cost less revenue earned from the sale of excess electricity, and that the cost of the heat produced by the power plant was the incremental cost of producing the heat in the boilers. Dividing the resulting figure by the electrical output in a year gives the unit cost of electricity for the year. An average cost of $5.39 \phi / \mathrm{kWh}$ was used for electricity bought in from the grid during the first year of operation, in calculating the savings made by generating electricity on site. Although the actual figure varied with the time of the day, it was the same for all seasons and it was assumed to escalate yearly at 2.1 per cent. Electricity was sold (bought back) to the grid at $3.47 \notin / \mathrm{kW} \mathrm{h}$, subject to the same environment as that bought in. This was assumed to be the avoided cost of production at a central generating facility.

In comparing $5.39 \mathrm{~d} / \mathrm{kW} \mathrm{h}$ with the figures for the cost of electricity produced by each plant, only the steam turbine alternative gives a higher figure, which is an indication that this proposal may not be economical. It is not always true that the cost of electricity generated by a cogeneration plant gives an indication of whether or not such a proposal is economically viable, as the figure obtained is dependent on the definition of electricity cost. The net present value or internal rate of return, although tedious to compute, must be looked at to arrive at a definite conclusion.

It should be mentioned that there are non-economic factors, such as environmental concerns, that are taken into consideration in deciding on a suitable alternative for a given duty. These become more important in the decision-making process when the economic analyses show marginal economic benefits between the top contending proposals. Certain issues, such as environmental emissions, can be accounted for in monetary terms, which can be catered for in the analysis through equipment or operation and maintenance cost. Frangopoulos and Caralis [4] described how to account for the impact of environmental issues when appraising energy systems. In the case examined here, both gas turbines used the same fuel, with the result that the economic penalties due to emissions would be comparable and, therefore, not significant in making the final decision. However, the large cooling needs of the combined cycle plant demand that more attention be paid to environmental issues than in the case of the gas turbine with HRSG.

Since there is a significant disparity between the economic performances of the two viable proposals, it is very unlikely that the gas turbine with HRSG will be chosen over the combined cycle option, unless the investment cost of the latter is found to be prohibitive. For the purposes of this paper, it is not necessary to carry out a sensitivity analysis, as the results obtained will not affect the final decision, but rather give an insight into the variables that need to be thoroughly scrutinized to ensure that the operational performance of the investment ties up well with the economic predictions.

\section{CONCLUSION}

A steam turbine, a gas turbine with HRSG and a gas/ steam turbine combined cycle cogeneration plant were investigated to find which one, if any, was most suitable to meet hypothetical energy demands at an industrial site, in an attempt to improve the energy situation at the site. Each unit was sized to produce the same thermal output. The power output varied significantly, with the combined cycle cogeneration plant giving the highest output and the steam turbine plant the lowest. Each unit met the electrical demand over the seasons, but during the winter months the thermal output was supplemented with heat from conventional boilers. The requirement that the existing boilers be kept was factored into the sizing of each plant. 
The combined cycle cogeneration plant gives the best thermodynamic performance, followed by the gas turbine with HRSG. The economic appraisals show that the revenue earned from the sale of excess electrical energy to the grid is the dominant factor in determining the economic viability of each proposal. The net present values are in the order of the excess electrical energy sold, which is highest for the combined cycle cogeneration plant and least for the steam turbine plant. Consequently, the combined cycle cogeneration proposal is the most viable option. A negative net present value is obtained for the steam turbine proposal, indicating that the proposal is uneconomical. The costs of electricity generated by the plants are in the same order of attractiveness as are the net present values.

The recommendation made is that the gas/steam turbine combined cycle cogeneration plant should be chosen to replace the existing energy system at the site. If, however, the first cost (investment) is prohibitive, the gas turbine with HRSG should be opted for. The steam turbine proposal should not be considered as it is uneconomical.

\section{ACKNOWLEDGEMENTS}

The author J. E. A. Roy-Aikins wishes to thank the
Alexander von Humboldt Foundation for providing financial support that initiated the work. Thanks go also to the Institute of Steam and Gas Turbines, Aachen University of Technology, for providing institutional support.

\section{REFERENCES}

1 Roy-Aikins, J. E. A. BRAKINE: a programming software for the performance simulation of Brayton and Rankine cycle plants. Proc. Instn Mech. Engrs, Part A, Journal of Power and Energy, 1995, 209(A2), 281-286.

21997 Gas Turbine World Handbook, 1997 (Pequot Publishing).

3 Williams, B. C. and McMullan, J. T. Techno-economic analysis of fuel conversion and power generation systemsthe development of a portable chemical process simulator with capital cost and economic performance analysis capabilities. Int. J. Energy Res., 1996, 20, 124-142.

4 Frangopoulos, C. A. and Caralis, Y. C. A method for taking into account environmental impacts in the economic evaluation of energy systems. In Proceedings of the Conference on Efficiency, Costs, Optimization, Simulation and Environmental Aspects of Energy Systems, 1996, pp. 485-494. 